\title{
両側反回神経麻瘒における囁語の語音調節
}

\author{
東 川 雅 彦・坂 倉淳・高 橋 宏 明
}

\section{Articulatory Adjustment during Whispering in Bilateral Recurrent Nerve Palsy}

\begin{abstract}
Masahiko Higashikawa, Atsushi Sakakura and Hiroaki Takahashi
A perceptual study of whisper uttered by patients with bilateral recurrent nerve palsy (BRNP) revealed that, frequently, five vowels were perceived as syllables $/ \mathrm{hV} /$ and voiced fricative consonants were perceived as voiceless ones. Sound spectrographic analysis of the uttered samples showed that vowels uttered by BRNP had noise at the initial portion of the utterances like in a breathy voice onset and that voiced consonants uttered by BRNP had no formant transitions. On the other hand, the airflow rate in BRNP was very high during phonation and it was difficult for the patients to control the airflow. It was suggested that this difficulty of airflow control caused the decrease of the articulatory adjustments in BRNP.
\end{abstract}

Key words : 両側反回神経麻瘏, 囁語, 語音調節, 音響分析

$$
\text { は じめに }
$$

両側反回神経麻痺のおもな症状は呼吸困難と, 発声障害 である. 実際には呼吸困難の頻度が多く, その治療として いくつかの声門開大術が考案されている ${ }^{1)}$. 一方発声障害 が生じた際は, それが高度である場合には声帯内シリコン 注入などがおこなわれる2).

呼吸困難のない場合の両側反回神経麻痺患者の音声は, 声門間隙が大きいため規則的な声帯振動が得られず雑音成 分が多くなる．この点において囁語と類似した音声になっ ていると考えられる。

今回, 呼吸困難を来すことなく経過した両側反回神経麻 瘏患者の, 㖩語による音声と通常発話時の音声を比較し, それらの語音調節がどのようにおこなわれているかについ て検討した。

症例

症例 149 才性

主訴 : 嗄声, 労作時呼吸困難

現病歴：甲状腺癌 (papillary carcinoma) の診断で昭 和 60 年 9 月右葉切除, 術後右反回神経麻痺を認めた。平成 2 年 4 月, 嗄声, 労作時呼吸困難が出現, 左葉に甲状腺癌 の再発を認め, その圧迫による左反回神経麻痺を認めた。 左葉切除をおこなった結果呼吸困難は改善するも嗄声は残 る.

喉頭所見：両側声帯とも中間位に固定.

発声機能検査 : GRBAS 尺度は, G3R3B2A0S0であっ た. 発声持続時間 (MPT) は, 通常発話では1.6秒, 囁語
では2.2秒, 発声呼気量は, 通常発話では $80 \mathrm{~dB}$ の強さで毎 秒 $1000 \mathrm{ml}$ 以上と測定レンジをオーバー, 囁語では平均 50 $\mathrm{dB}$ の強さで毎秒 $800 \mathrm{ml}$.

呼吸機能検査 : FVC 2.73L, FEV 1.0\% 84.2\%, \% VC $110.0 \mathrm{~L}$

症例 227 男性

主訴 : 交通外傷後の嗄声

現病歴: 平成 3 年 2 月 7 日, 交通事故の際, ハンドルで 前頚部を強打, 甲状軟骨輪状軟骨離断を生じ救急処置をう けた．その後嗄声が残るため耳鼻科を受診した。 喉頭所見 : 両側声帯とも中間位に固定. 発声機能検査: GRBAS 尺度は, G3R2B3A0S0, MPT は通常発話では1.4秒, 囁語では2.1秒であった。 呼吸機能検查: FVC 4.29L, FEV 1.0\% 78.8\%, \%VC 109.7L

\section{方法}

1 ）反回神経麻瘏患者

発話条件は囁語, 通常発話, それぞれ楽な高さ, 強さの 発話とした．ただし通常発話は症例 1 についてのみおこなっ た.

発話サンプルは単音節で, 母音 $[\mathrm{a}],[\mathrm{i}],[\mathrm{u}],[\mathrm{e}],[\mathrm{o}]$, と, 子音 $[\mathrm{h}],[\mathrm{k}],[\mathrm{g}],[\mathrm{t}],[\mathrm{d}],[\mathrm{p}],[\mathrm{b}],[\mathrm{s}],[\mathrm{z}]$ を組み合わせた。聴取テストでは耳鼻咽喉科医局員 20 名を 聴取者とした。

音響分析には, sampling $10 \mathrm{kHz}$ で $\mathrm{AD}$ 変換の上, Mac Speech LabIIを用いた。おもにformant transitions の 有無について調べた。 
ファイバースコピーにより㵵語，通常発話，および安静 時の時の喉頭を観察し, 症例 1 についてはVTR へ録画し た。

\section{2 ) 正常発話者}

両側反回神経麻舫患者と正常発話者の囁語の語音調節と の違いを調べるために，健康な男女各 6 名の楽な高さ強さ での囁語ついての受聴明瞭度を調べ，発話サンプルの音響 分析をおこなった。聴取者は耳鼻咽喉科医局員 8 名を含む 24名とした。

$$
\text { 結果 }
$$

1) 聴取テスト

表 1 に反回神経麻盘患者の，母音と八行の発語明瞭度 confusion matrix を示す。上段は啰語，下段は通常発話 である．囁語では 5 母音とも対応する八行に聴かれる傾向 を認めた，八行の聞き違えはほとんどなかった，通常発話 の場合は, /a/, / / /, /o/の半数以上が対応する八行の各 音に聞かれていたが, 㖩語の場合ほどの頻度ではなかった。 なお，正常発話者の囁語における母音の受聴明瞭度は $90 \%$ 以上，八行の受聴明瞭度は $80 \%$ 以上で相互に聞き違えられ ることはほとんどなかった $(\mathrm{p}<0.01)$.

表 2 に反回神経麻痺患者の，対立する無声・有声子音を 有する音節の発語明瞭度 confusion matrix を示す。囁語

表 1 両側反回神経麻瘴患者の母音と八行の

発語明暸度 confusion matrix.

（上段は敪語，下段は通常発話）

whisper

\begin{tabular}{|c|c|c|c|c|c|c|c|c|c|c|c|}
\hline & \multicolumn{10}{|c|}{ perceived } \\
\hline & & あ & $w$ & j & え挍 & は & ひ & 京 & 乞 & ほ & その他 \\
\hline \multirow{10}{*}{ produced } & あ & 0 & & & & 40 & & & & & \\
\hline & $w$ & & 0 & & & & 40 & & & & \\
\hline & j & & & 3 & & & & 34 & & & は2, あ1 \\
\hline & え & & & & 2 & & & & 38 & & \\
\hline & 掠 & & & & 0 & & & & & 40 & \\
\hline & は & 0 & & & & 40 & & & & & \\
\hline & ひ & & 1 & & & & 39 & & & & \\
\hline & ふ & & & 0 & & & & 40 & & & \\
\hline & へ & & & & 0 & & & & 40 & & \\
\hline & ほ & & & & 0 & & & & & 39 & ほ1 \\
\hline
\end{tabular}

vocal

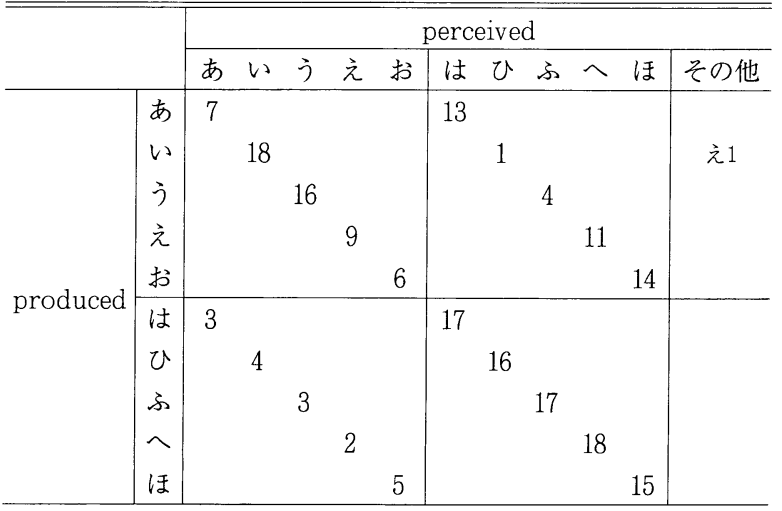

では破裂音の有声子音のほとんどが無声子音として聞かれ ていた。摩擦音ではその頻度は少ないが, [z] が [t] と聞 かれたものがあとに示す正常発話者の場合より多くみられ た. 通常発話時では, 囁語の場合よりは有声子音が無声子 音に聞かれる頻度は少なかった。

正常発話者の啰語の confusion matrix を表 3 に示す. 有声子音の無声子音への異聴はみられるものの, 正答の方 が有意性をもって多かった $(\mathrm{p}<0.01)$. 聞き違えの頻度は 反回神経麻瘏患者における㖩語, あるいは通常発話の場合 と比べると低かった。

2 ) 音響分析

図 1 の上段, 中段は症例 1 の囁語と通常発話, 下段は正 常発話者の焣語のサウンドスペクトログラムを示す。発話

表 2 両側反回神経麻痺患者の対立する無声・有声子音 を有する単音節発語明瞭度 confusion matrix. （上段は啰語，下段は通常発話）

whisper

\begin{tabular}{c|c|cc|cc|cc|cc|c}
\hline \hline \multicolumn{2}{c|}{} & \multicolumn{7}{c}{ perceived } \\
\cline { 3 - 10 } \multicolumn{1}{c|}{} & $\mathrm{k}$ & $\mathrm{g}$ & $\mathrm{t}$ & $\mathrm{d}$ & $\mathrm{p}$ & $\mathrm{b}$ & $\mathrm{s}$ & $\mathrm{z}$ & Others \\
\hline \multirow{5}{*}{ produced } & $\mathrm{k}$ & 190 & 7 & & & & & & & 3 \\
& $\mathrm{~g}$ & 191 & 9 & & & & & & & \\
\hline & $\mathrm{t}$ & 9 & & 183 & 2 & 6 & & & & \\
& $\mathrm{~d}$ & 5 & & 87 & 26 & 2 & & & & \\
\cline { 2 - 10 } & $\mathrm{p}$ & 2 & & & & 195 & 3 & & & \\
& $\mathrm{~b}$ & 2 & & & & 189 & 7 & & & 4 \\
\hline & $\mathrm{s}$ & & & 9 & & & & 178 & 10 & 3 \\
& $\mathrm{z}$ & & & 80 & & & & 66 & 52 & 2 \\
\hline
\end{tabular}

vocal

\begin{tabular}{c|c|cc|cc|cc|cc|c}
\hline \hline \multicolumn{2}{c|}{} & \multicolumn{7}{c}{ perceived } \\
\cline { 2 - 10 } \multicolumn{1}{c|}{} & $\mathrm{k}$ & $\mathrm{g}$ & $\mathrm{t}$ & $\mathrm{d}$ & $\mathrm{p}$ & $\mathrm{b}$ & $\mathrm{s}$ & $\mathrm{z}$ & others \\
\hline \multirow{5}{*}{ produced } & $\mathrm{k}$ & 92 & 5 & & & & 1 & & & 2 \\
& $\mathrm{~g}$ & 83 & 14 & & & & & & & 3 \\
\hline & $\mathrm{t}$ & 3 & & 91 & 3 & & & & & 3 \\
& $\mathrm{~d}$ & & & 51 & 9 & & & & & \\
\hline & $\mathrm{p}$ & & & & & 83 & 16 & & & 1 \\
& $\mathrm{~b}$ & & & & & 59 & 32 & & & 9 \\
\hline & $\mathrm{s}$ & & & 1 & & & & 97 & 2 & \\
& $\mathrm{z}$ & & & 29 & & & & 29 & 41 & 1 \\
\hline
\end{tabular}

表 3 正常発話者の囁語における受聴明瞭度 confusion matrix.

whisper (normal speaker)

\begin{tabular}{|c|c|c|c|c|c|c|c|c|c|c|}
\hline & \multicolumn{9}{|c|}{ perceived } \\
\hline & & $\mathrm{k}$ & g & $\mathrm{t}$ & $\mathrm{d}$ & $\mathrm{p}$ & $\mathrm{b}$ & $\mathrm{s}$ & $\mathrm{z}$ & others \\
\hline \multirow{8}{*}{ produced } & $\mathrm{k}$ & 840 & 140 & 2 & 1 & 1 & & & 1 & 6 \\
\hline & g & 399 & 613 & 2 & & & & & 7 & 54 \\
\hline & $\mathrm{t}$ & 2 & 1 & 916 & 61 & 17 & & 13 & 49 & 16 \\
\hline & d & & 3 & 324 & 242 & 3 & 8 & & 1 & 64 \\
\hline & $\mathrm{p}$ & 1 & & 8 & 1 & 942 & 84 & & & 39 \\
\hline & $b$ & 4 & & 1 & 1 & 559 & 439 & & & 71 \\
\hline & S & & & & & & & 912 & 75 & 4 \\
\hline & z & & & 257 & & & & 7 & 805 & 6 \\
\hline
\end{tabular}



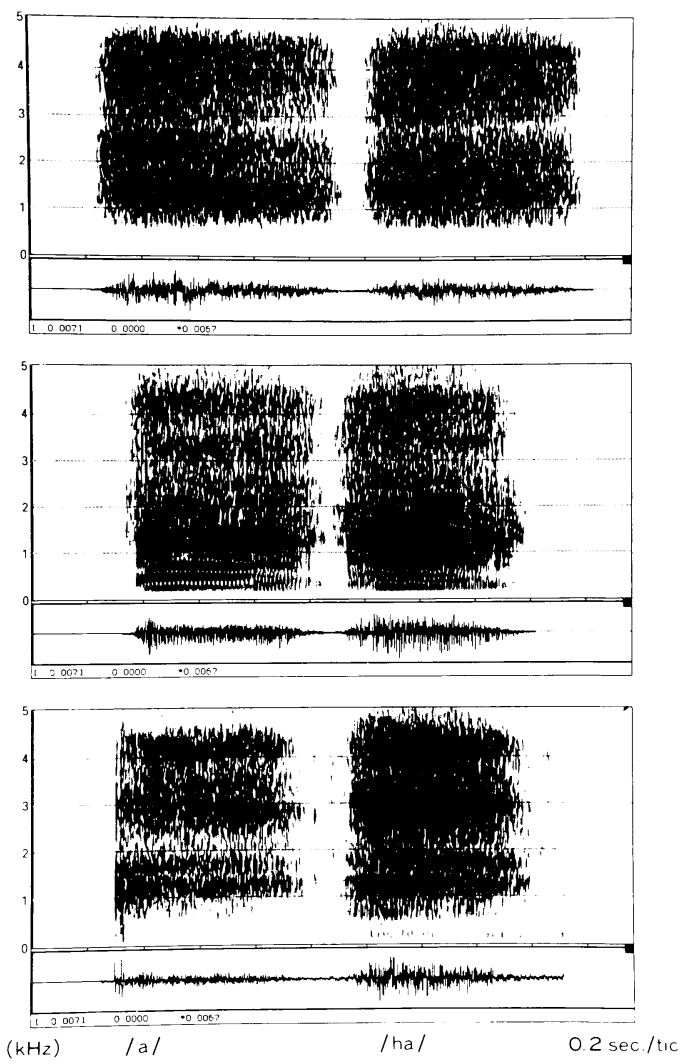

図 $1 / \mathrm{a} /$ と/ha/の比較. (上段は症例 1 の囁語, 中段は症例 1 の通常発話, 下段は正常発話者の囁語）
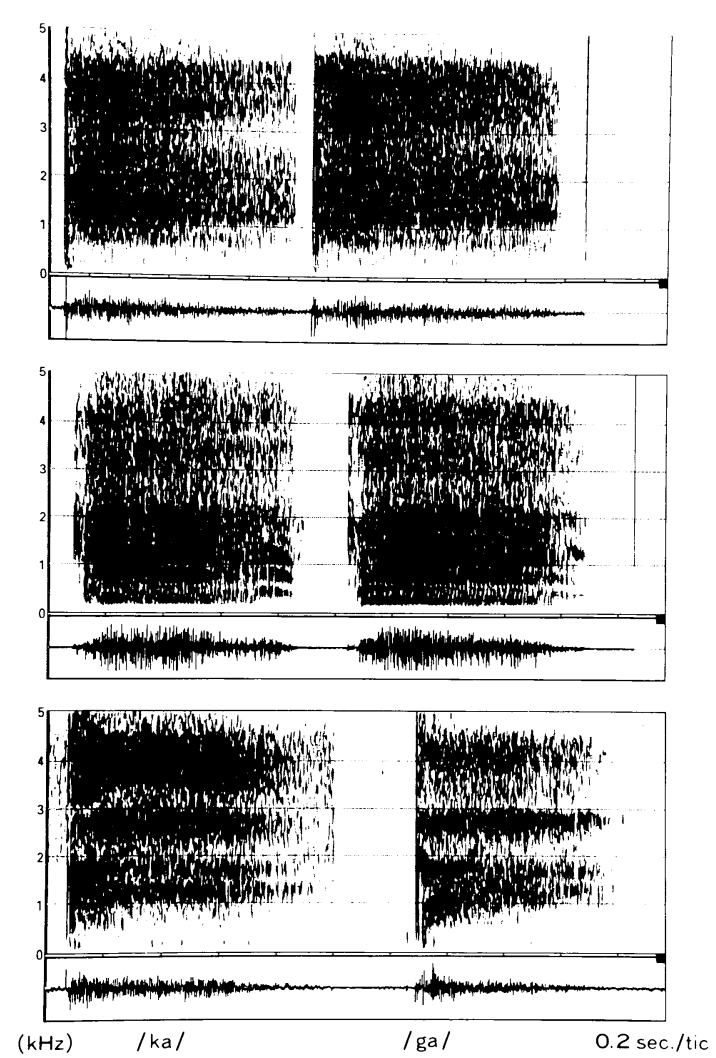

図 $2 / \mathrm{ka} /$ と $/ \mathrm{ga} /$ の比較。(上段は症例 1 の囁語，中段は症 例 1 の通常発話, 下段は正常発話者の聶語)
表 4 formant transitions の有無と受聴明瞭度の関係. (FT : formant transitions)

\begin{tabular}{r|c|c|c}
\hline \hline & $/ \mathrm{ka} /, / \mathrm{ga} /$ & $/ \mathrm{ta} /, / \mathrm{da} /$ & $/ \mathrm{pa} / / \mathrm{ba} /$ \\
\hline $\mathrm{P}<0.01$ で弁別できたサンプル & & & \\
$\mathrm{FT}$ が指摘できる & 9 & 5 & 1 \\
$\mathrm{FT}$ が指摘できない & 0 & 1 & 2 \\
\hline $\mathrm{P}<0.01$ で弁別できなかったサンプル & & & \\
$\mathrm{FT}$ が指摘できる & 1 & 3 & 1 \\
$\mathrm{FT}$ が指摘できない & 2 & 3 & 8 \\
\hline
\end{tabular}

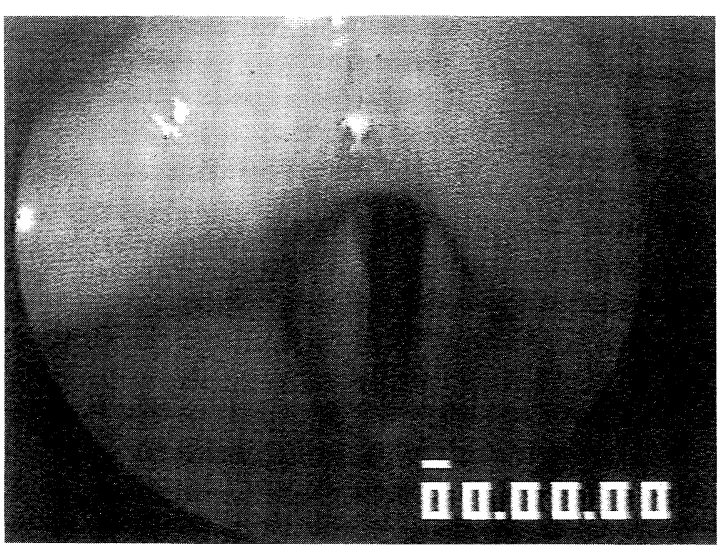

図 3-a

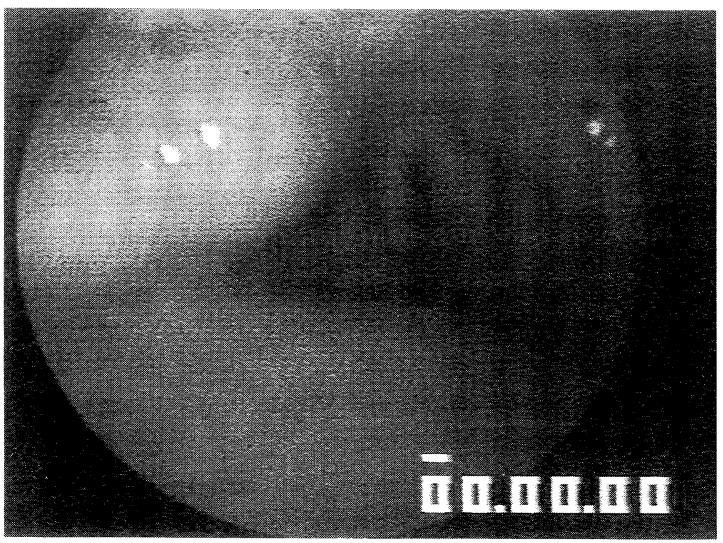

図 3-b

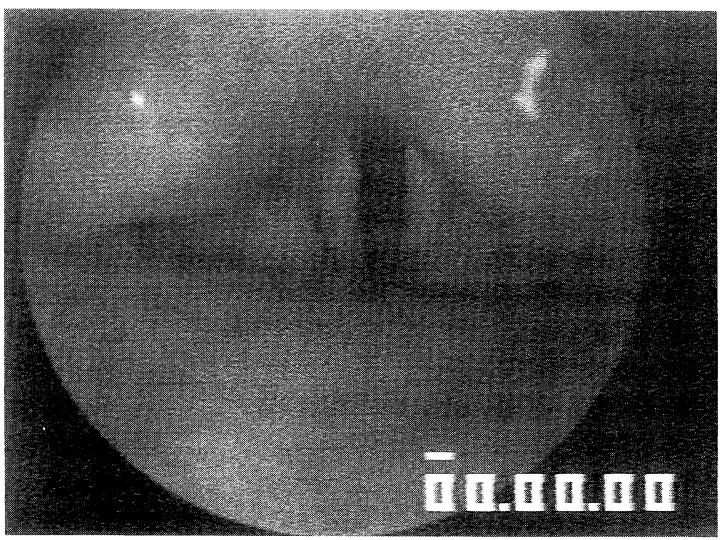

図 3-c

図３ファーバースコピーによる両側反回神経麻瘒患者（症 例 1 ) の㬋頭所見.（ $a$-は安静時, $b$-は通常発話 /e/, c一は囁語発話/e/) 
サンプルはそれぞれ/a/と/ha/である．反回神経麻舫患者 の囁語の場合は，/a/のフォルマントが出現する以前から 雑音成分が見られた。一方, 正常発話者の囁語の/a/では, 声門の開放によるbarの直後よりフォルマントが出現し, /ha/と比較するとその差は明らかであった．中段の反回 神経麻痺患者の通常発話でも/a/と/ha/の差は見られるが, 正常発話者に比べると明らかではなかった.

図 2 の上段, 中段は症例 1 の囁語と通常発話, 下段は正 常発話者の囁語の, / ka/と/ga/のサウンドスペクトログ ラムを示す. 正常発話者の/ga/において formant transitions を認めるが $/ \mathrm{ka} /$ では認めない. 一方, 反回神経麻瘒 患者では, 啰語, 通常発話ともにformant transitions は 認めなかった。

正常発話者12名について, / ka/と/ga/, / ta/と/da/, /pa/と/ba/のすべてのサンプルについて, formant transitions の有無と, 聴取率について調べた結果が表 4 であ る. 有声, 無声子音の判別の良いサンプルほど有声子音 で formant transitionsがみられ，それは/ga/, /da/, /ba/の順に明らかであった。

3 ) 喉頭所見について

安静時, 声帯は中間位に固定していた（図 $3-\mathrm{a}$ ). 通 常発話時喉頭全体は狭小化し, それにつられて声門間隙は 狭くなり (図 $3-b)$, 声帯はときおり規則的に振動した. 囁語発話時においても喉頭の狭小化は生じるもののその程 度は弱く, 声門間隙は㖩語発話時には, 通常発話時に比べ て広いようであった（図 $3-\mathrm{c}$ ).

また, 囁語で強く発話 (stage whisper) するよう指示 したところ, 声門間隙は楽な㖩語を発するときに比べてや や狭まり, 声帯振動が認められることがあった.

\section{考案}

両側反回神経麻痺症例の㖩語で興味のある点の一つは, 喉頭の調節が制限されているにもかかわらず㖩語, 通常発 話の出し分けができることである. 今回の検討で両側反回 神経麻痺があっても囁語も成立することが確認された。 た, その出し分けの調節には喉頭の動きの観察と, 発声呼 気量の測定の結果から呼気流量が関わり，それを大きくす ることにより通常発話を, 小さくすることにより囁語を発 していることが示唆された.

一方, 両側反回神経麻瘏患者の音声の明瞭度は正常発話 者のそれに比べて低い傾向にあり, 両側反回神経麻痺患者 の啰語の語音調節には不十分な点があると考えた。缉語の 発語明瞭度で明瞭度の悪かったものは, 母音と, 無声・有 声の対立のある子音であった。

母音は，そのほとんどがそれぞれ対応する/ $\mathrm{hV} /$ に聞き 違えられていた。これは反回神経麻痺のために声門の閉鎖 がおこなえず，母音の起声の多くが気息性になっていたた めと考えられる．気息性となっている部分はスペクトログ ラム上, 母音の語頭の雑音成分として確認された.また母 音の発語明瞭度は, 囁語に比べて通常発話のほうが良好で
あった。通常発話時の呼気流量は $1000 \mathrm{ml} / \mathrm{sec}$. 以上と非常 に大きく，そのために声門間隙があるにも拘らず，声帯を 振動させることが可能となっている. その結果母音部分の 勢力が強調され，母音として聞かれやすくなったことが発 語明瞭度の良かった理由であろう。

有声・無声の対応のある子音では，破裂子音の有声が無 声に, 摩擦子音の無声が有声に聞き違えられる傾向がみら れた. 有声・無声の判別の手がかりは正常者の通常発話の 場合でも不明な点が多いが, 音響学的な手がかりの一つと してVOT と formant transitions の有無があげられてい る3).囁語においては formant transitions の有無が重要 と考え検討した結果, 正常発話者においては/ga/, / da/, /ba/の順に formant transitions が明らかで，それは受 聴明瞭度の良さに対応していた. 一方, 両側反回神経麻痺 患者の発話サンプルで formant transitions を認めること はなく, 発語明瞭度も悪かった.

この formant transitions が両側反回神経麻瘏患者で認 められなかったことは, 構音点の調節と, 発話のための呼 気流をつくる調節のタイミングが, 正常発話者に比較して ずれているためと考えた.すなわち構音調節には口腔内圧 が必要であるが, 声門間隙が常にあるためそれらが十分得 られないうちに起声がはじまり，その結果有声・無声子音 の判別をおこなう構音点での調節が不十分になったと考え られる。このことは両側反回神経麻痺患者のみならず, 声 門間隙の大きい病的喉頭者についても同様のことが生じる と考えられ，今後検討を要するところである.

囁語の生理学的な喉頭調節については, 角田らによる内 喉頭筋の筋電図学的検討の報告があるが，それによると有 声・無声子音間で電位の立ち上がりに差を認めている ${ }^{4)}$.

この所見は反回神経麻痺のために内喉頭筋の働きが失われ たことも異聴の一因となっていることを示すと考えられた.

また今回の反回神経麻瘏症例の音声で興味がもたれた点 は, その聴覚印象は音の強さという点を除いて通常発話よ り囁語のほうがよいということである。このような声門間 隙の大きい喉頭疾患症例において, 㖩語がコミュニケーショ ンの一手段となりうるかについての検討もおこなっている.

\section{ま と め}

両側反回神経麻瘏患者 2 名の囁語, 通常発話の語音調節 について調べた。

囁語と通常発話の出し分けは, おもに発声呼気量によっ て調節していると考えられた。

両側反回神経麻痺患者の発語明暸度は通常発話, 囁語と もに, 正常発話者の囁語の受聴明瞭度に比べて低い傾向に あり，とくに囁語において著明であった。㵵語の発語明瞭 度の悪かったものは, 母音と, 有声 ·無声の対立のある子 音であった。

母音は，そのほとんどがそれぞれ対応する/hV/に聞き 違えられていた。これは母音の起声の多くが気息性になっ ていたためと考えられる. 
無声・有声の対応のある子音では, 破裂子音の有声が無 声に, 摩擦子音の無声が有声に聞き違えられる傾向がみら れた．音響分析の結果，正常発話者の㖩語のサンプルで認 められた formant transitions が両側反回神経麻瘏患者の サンプルでは認められず, formant transitions の有無が 囁語における無声・有声の判別の手がかりになっているこ とが明らかにされた。

\section{文}

\section{献}

1）小林武夫：両側声帯麻痺. 喉頭麻痺（廣瀬 肇，石 井英男編著), 256 265, 文光堂, 東京, 1992 .

2）牛島達次郎ほか：両側反回神経麻痺に対する声帯内
シリコン注入術の 1 例. 音声言語医学 $30: 72 \sim 73$, 1989.

3) Kenneth N.S. and Klatt D.H. : Role of Formant Transitions in the Voiced-Voiceless Distinction for Stops. J Acoust Soc Am 55 : 653 659, 1974.

4）角田晃一ほか：㖩語の喉頭調節について，音声言語 医学 $32: 90 \sim 91,1991$.

別刷請求先 $\overline{\mathbf{T}} 569$ 高槻市大学町 2-7 大阪医科大学耳鼻咽喉科学教室 東川雅彦 